University of Nebraska - Lincoln

DigitalCommons@University of Nebraska - Lincoln

3-2020

Integration of and Deliveries among the World Zionist

Organization, Israel, and Diaspora Countries: System Articulation with the Social Fabric Matrix

F. Gregory Hayden

Follow this and additional works at: https://digitalcommons.unl.edu/econfacpub

Part of the Economic History Commons, Economic Theory Commons, Growth and Development Commons, International Economics Commons, Macroeconomics Commons, Political Economy

Commons, Public Economics Commons, and the Regional Economics Commons

This Article is brought to you for free and open access by the Economics Department at DigitalCommons@University of Nebraska - Lincoln. It has been accepted for inclusion in Economics Department Faculty Publications by an authorized administrator of DigitalCommons@University of Nebraska - Lincoln. 
Citation: F. Gregory Hayden \& Erin Johnson (2020) Integration of and Deliveries among the World Zionist Organization, Israel, and Diaspora Countries: System Articulation with the Social Fabric Matrix, Journal of Economic Issues, 54:1, 97-123, DOI: 10.1080/00213624.2020.1720568

Published 4 March 2020.

\title{
Integration of and Deliveries among the World Zionist Organization, Israel, and Diaspora Countries: System Articulation with the Social Fabric Matrix
}

\author{
F. Gregory Hayden \& Erin Johnson
}

F. Gregory Hayden and Erin Johnson are respectively professor and student of economics at the University of Nebraska-Lincoln. The authors thank the anonymous reviewers for their comments.

\begin{abstract}
The religious economics (not economics of religion) concern here is the relationship between the World Zionist Organization (WZO) and Israel, which is known as a geopolitical power in its region and which is also known as an economic success story. Joseph Schumpeter and Karl Polanyi explained how the political economy of medieval Europe was influenced and guided by Christian morality. This paper extends the analysis of religious economics by using the social fabric matrix of original institutional economics to define and structure the integration of the WZO, Israel, and the Diaspora countries. This allows us to observe how to conduct such work and to learn how Israel is guided and influenced by the WZO. It also helps to explain Israel's "risk of tearing itself apart" as noted in a recent article in the New York Times.
\end{abstract}

Keywords: beliefs, instrumentalism, political economy, Israel, Zionism

JEL Classification Codes: F53, F55, Z12, Z13 
The relationship between religion and the political economy has an extended history in economic literature, as numerous economists have written about the influence of religion on the political economy of various countries and regions. Joseph Schumpeter and Karl Polanyi explained how the relationships among kings, aristocracies, and the Catholic Church of Europe formed the political economy during the period that extended from the feudal period through the Holy Alliance. That accord came from the enforcement of a unity of thought based on Christian beliefs. "The kings, and aristocracies of Europe formed an international of kinship; and the Roman Church provided them with a voluntary civil service ranging from the highest to the lowest rung of the social ladder in Southern and Central Europe" (Polanyi 1994 [2001], 9). The economic base "consisted of the dependent peasants and manorial craftsmen on whose work the [feudal] warriors lived" (Schumpeter 1954 [1963], 74). However, the civil service of monks and friars kept the Church in control. Religious ideas from the Church were articulated in the theological works of monks and friars then disseminated by priests in churches during Sunday sermons and other holy days. The kings and aristocracies had the swords, soldiers, and knights, but the Church controlled the ideas and ideals in peoples' minds. There was a factor "that the warrior class failed to absorb or to conquer, for us the most important of all, the Roman Catholic Church" (Schumpeter 1954 [1963], 75). "All those monks and friars spoke the same unclassical Latin; they heard the same Mass wherever they went; they were formed by an education that was the same in all countries; they professed the same system of fundamental beliefs; and they acknowledged the supreme authority of the Pope, which was essentially international ..." and the beliefs structured the socioeconomic system (Schumpeter 1954 [1963], 75-76). Below, we explain the World Zionist Organization (WZO) network that is devoted to an international commitment to Jewish beliefs. The WZO was founded in 1879 under the leadership of Theodore Herzl in order to promote the Zionist ideal of assuring a legal home for the Jewish people in Israel. In a recent article in the Journal of Economic Issues, Mehmet Karaçuka explains numerous studies that have compared religious networks to the economic institutions that perform "allocative, product, and adaptive efficiency ..." $(2018,67)$. The objective of Karaçuka's network research was "to study the effects of religion on economic performance by focusing on the institutional and organizational aspects of religious groups" $(2018,58)$. The article concentrated mainly on Protestant and Catholic communities in Europe and the United States. Our work here is 
concentrated exclusively on a comprehensive articulation of the network of the WZO in its effort to guide Judaism and influence the governing structure of Israel.

The purpose here is twofold. The first is to describe and explain the WZO as a system, and define the structure and deliveries made among its component parts within its governing body. "Institutional Economics is an analytical approach to the study of economies, which are patterned systems that are always and everywhere embedded in larger sociopolitical systems" (Mayhew 2018, 3). The patterned system is found by defining and structuring the WZO as a whole, which is accomplished by differentiating societal criteria and institutional organizations within the WZO and demonstrating how societal criteria and institutions come together to influence the governing structure of Israel. The articulation of the system processes is realized with the use of the social fabric matrix (SFM) and its corresponding digraph (Underwood and Friesner 2017; Fullwiler, Elsner, and Natarajan 2009; Hayden 2006). Each cell in the SFM where a delivery is indicated will be explained, and associated social indicator information will be presented for some of the cells. The findings here are new because such an effort to explain WZO's global system and its impact on Israel is not available in the literature.

The second purpose is to demonstrate how it is necessary for the SFM to be utilized to define a system so that a decision can be made about whether a system is instrumental or ceremonial. In his development of the SFM, "F. Gregory Hayden lays out a rigorous, comprehensive methodology ..." for the study of complex real-world systems. The SFM "methodology is philosophically and theoretically developed from, and consistent with, the original evolutionary-institutional economics (hereafter, OIE_- Original" Institutional Economics) and is one of the most comprehensive, empirical, and policy-relevant methodologies to come out of OIE" (Fullwiler, Elsner, and Natarajan 2009,1). The SFM is a "systematic attempt to identify the relevant set of influences that shape the behavior of a system... It is a picture of a system" (Gill 1996, 169). "The information needed for each [SFM] cell depends upon the context of the delivery and the problem being studied ..." (Fullwiler, Elsner, and Natarajan 2009, 12). Likewise, the components in the rows and columns depend on the context and problem being studied. "Each component is analyzed with an eye toward determining the flow and delivery of one component to another" (Sturgeon 2009, 42). This becomes clear below with the SFM and digraph for the WZO system. The SFM specifies the deliveries among the components, and the digraph 
(directed graph) provides the picture of the WZO system network (as network digraphs are often presented in scientific work in general). Digraph figures, about how the taxonomy of different component categories of the SFM are related and deliver to each other, have been presented numerous times and need not be repeated here. Such presentations include F. Gregory Hayden (2006, 18; 2009, 108; and 2018, 352); Scott Fullwiler, Wolfram Elsner, and Tara Natarajan (2009, 10); and Richard Adkisson 2009, 34). The WZO SFM below is consistent with the relationships specified in those figures about the deliveries among SFM components. The SFM has a central role in providing an evaluative tool for institutional economists to use to make instrumental-ceremonial judgments.

The instrumental-ceremonial dichotomy is the conceptualization recommended in OIE for making welfare judgments about a system. "Instrumental behavior covers a broad range of learned activities. It forms correlated patterns based upon and deriving from a functional process. Instrumental behavior derives from sequences of cause and effect, understanding of consequences, warranted experimental/scientific knowledge, trial and error, and instrumental logic" (Sturgeon 2009, 40). It stands in contrast to ceremonial behavior, which "is also defined to cover a broad range of learned behavior and it too forms correlated patterns. Its patterns come from and are validated by processes comprising myths, legends, and traditions" (Sturgeon 2009, 40). In both instrumental and ceremonial behavior are "the arts of associate living, the rules, customs, laws, ideologies, accumulated folklore, myths, licenses, policies, and traditions ... [and] the SFM may be used to discover and reveal these patterns of association ..." (Sturgeon 2009, 41).

In separate articles, Vladislav Valentinov et al. (2018) and Anne Mayhew (2018) explain that the evolution of OIE has included a divergence of instrumental theory into two camps. A problem is that both camps have depended too much on abstract statements drawn from limited and casual analysis in their advice about how to conduct instrumental-ceremonial judgments, rather than depending on the articulation of holistic complex systems as demonstrated below for WZO. That is, both camps have failed to specify the relationships and deliveries among components in real-world systems and failed to define the criteria to be used for making judgements. To make judgments, criteria have to be established. Thus, one of the important contributions to OIE literature is that made by Paul Bush (1983 and 1987) and further developed by Wolfram Elsner (2012) in which they emphasized that before 
decisions can be made about how instrumental a system is, the values and beliefs that are to serve as the criteria for judgment have to be articulated. Walter Neale (1980) explained that it is the values and beliefs of the real-world system being analyzed that are to be the criteria for judgment; therefore, they need to be included in the analysis of a system. Consistent with the integration of the concepts of Bush, Elsner, and Neale, we see how the Zionist cultural value of "To Uphold the Covenant" and social beliefs are used in the WZO system presented below to make judgments about how institutions are to function. In addition, both camps have generally failed to specify the relationships and deliveries among components that are necessary to understand real-world systems. The value and belief criteria relevant to the WZO are included in the SFM below as infinitive phrases, consistent with standards for judgment statements.

Once a system is detailed through the SFM, the researcher can determine which indicators ought to be gathered from the real world in order to access the consequences ... according to instrumental criteria" (Fullwiler, Elsner, and Natarajan 2009, 18). In the SFM approach to analysis, as explained by Fullwiler, Elsner, and Natarajan, real-world systems of values and social beliefs lead to social goals and to quantification through the use of models $(2009,19)$. "Via the SFM, the researcher has a method of organizing research that embeds a holistic, social systems perspective within it that is consistent with the relevant beliefs, values, and norms involved in the system (Fullwiler, Elsner, and Natarajan 2009, 18).

\section{The Social Fabric Matrix and Digraph}

As stated above, the SFM is an analytical aid that helps describe a system. It allows for the convergence and integration of diverse forms of knowledge, information, and values-based inquiry to describe the system, while creating a space to identify opportunities or gaps in information. The SFM "provides an analytical framework to identify and systematically trace flow relationships between players in any socioeconomic setting" (Underwood and Friesner 2017, 814). It "defines system elements, organizes them in a Boolean reachability matrix and identifies directional connectivity by way of transaction flows" (Underwood and Friesner 2017, 820). This is expressed below when the SFM demonstrates the patterned system in which Israel 
is embedded in the global WZO system. Through the SFM, one can articulate and analyze the system of focus and generate social indicators for future monitoring. There are seven major characteristics of the SFM itself: (1) it is based on the concept of delivery, (2) rows deliver to the columns, (3) it is a noncommon-denominator matrix (meaning all kinds of data can be incorporated), (4) cell observations are the flows of the system ..., (5) the number of cells is dependent on the study at hand, (6) the matrix defines the system as it exists, and (7) the matrix allows for model building and data collecting consistent with theory. (Sturgeon 2009, 42)

The SFM digraph expresses the delivery paths within the SFM by illustrating the direct relationship between components. The digraph allows for "a pictorial display of the delivery and flows of the elements connected in the SRM" (Sturgeon 2009, 42). Each component in the SFM is included in the digraph in a box, where the edges (lines, links) with arrows pointing inward or outward represent the deliveries made to and from each component. The edges in the digraph represent the cells in the SFM. The SFM cell deliveries are defined, described, and explained in the body of the paper. Deliveries between rows and columns in the matrix are indicated with the number 1 . Rows may deliver to multiple columns. Information provided in a row/column relationship is explained fully in the first instance, and the reader will be referred back to the cell where it was originally explained upon the reappearance of that information, to avoid unnecessary repetition. Concluding remarks follow the explanation of SFM cell descriptions.

\section{Cell Descriptions of the Zionist-Israeli Social Fabric Matrix and Digraph}

Figure 1 is the SFM that structures the integration of WZO and Israel, and Figure 2 (found on pages 106-107) is the digraph of the same derived from Figure 1. The explanation of the cells of Figures 1 and 2 follow. There is no SFM without the cellular information that defines the deliveries, and, therefore, the relationships among the components that makeup the system. Without an understanding of the cellular information in the applied SFM in Figure 1, it is not possible to demonstrate the importance of religion on the economic life of Israel, as found below. The details of the religious influence as articulated in the cellular information in Figures 1 and in the SFM digraph in Figure 2 demonstrate the conflicts in the system. ${ }^{1}$ 


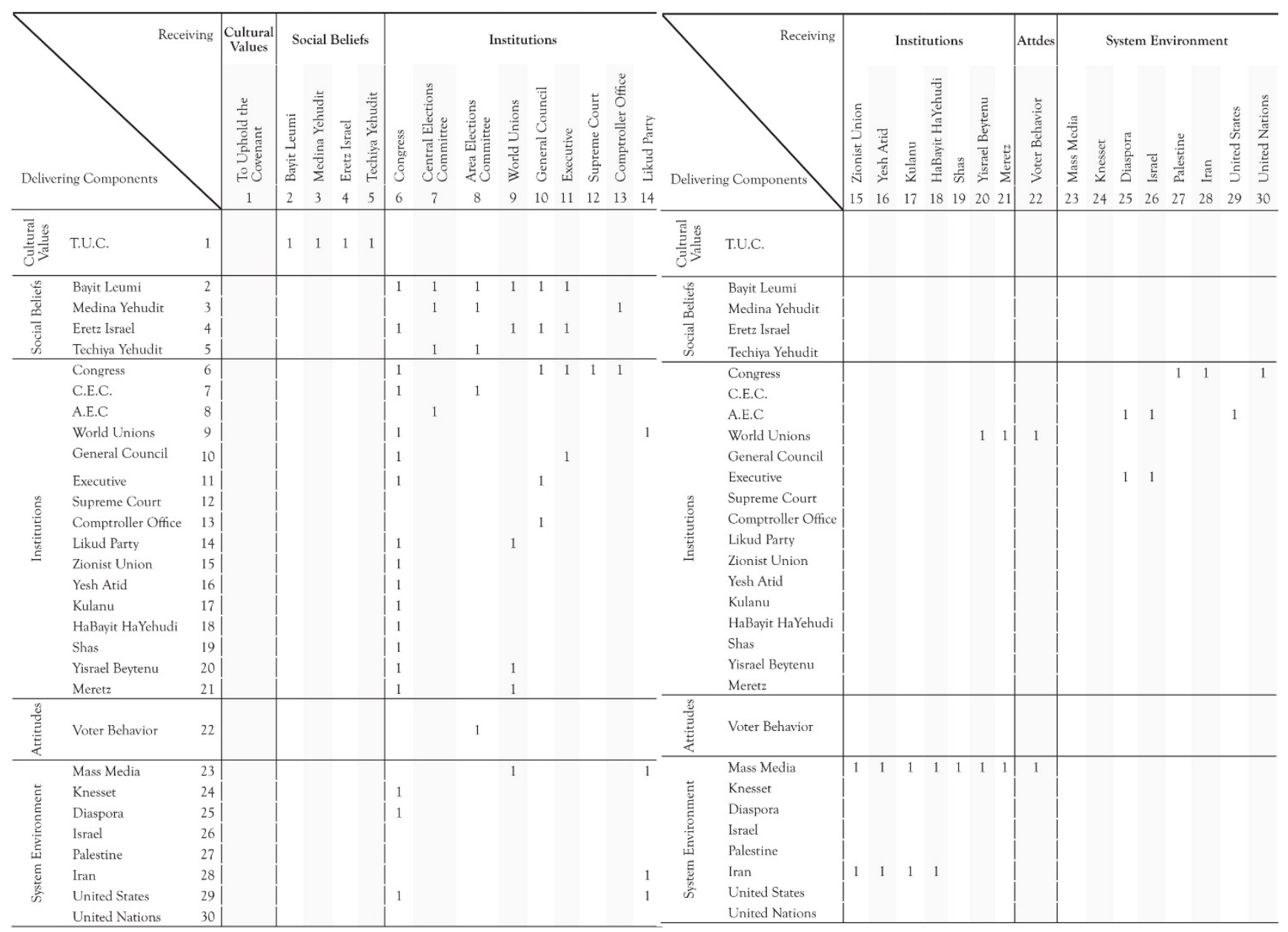

Figure 1. SFM of Deliveries among WZO, Israel, and Diaspora Countries 


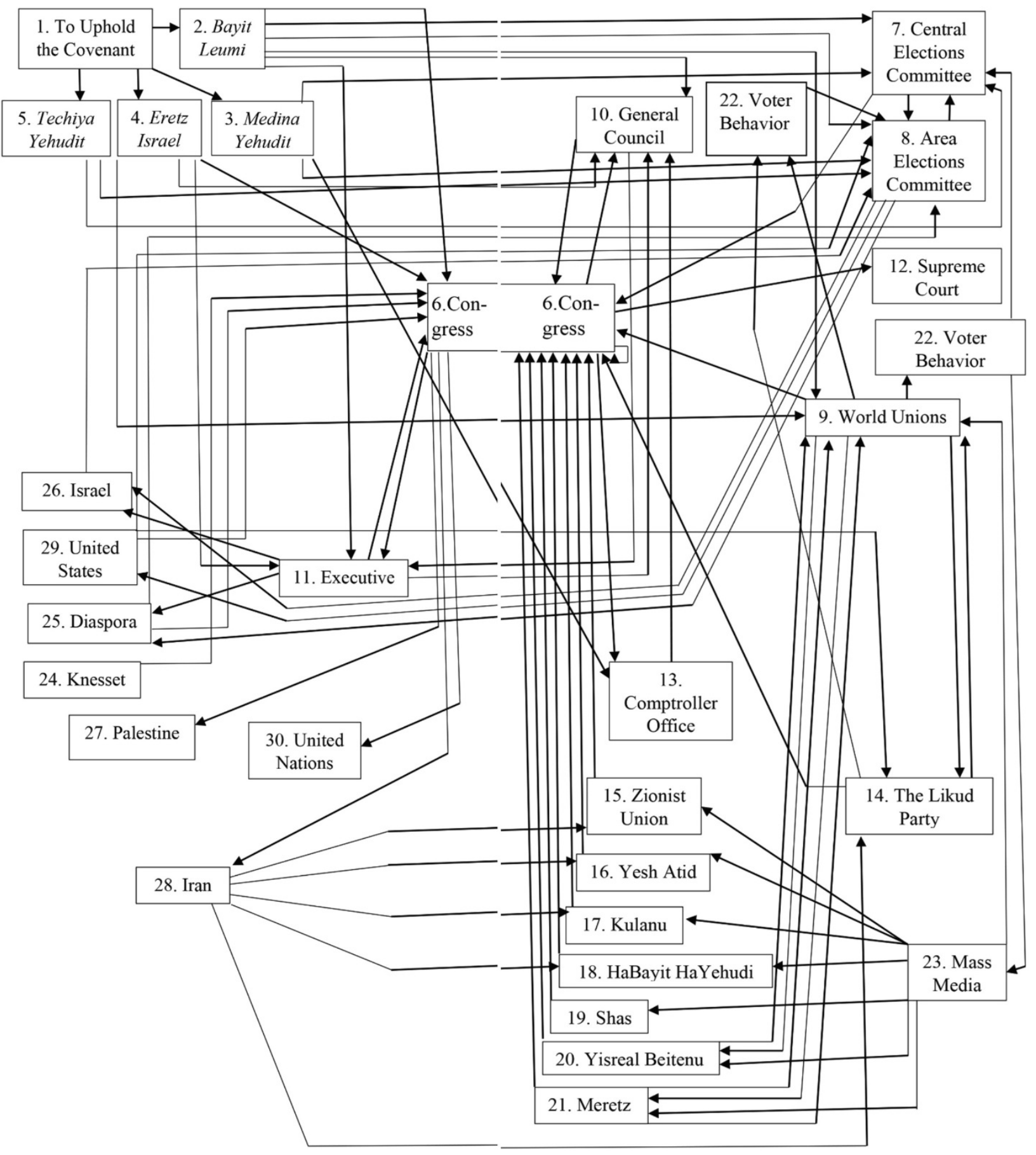

Figure 2. SFM Digraph of Deliveries among WZO, Israel, and Diaspora Countries 
As explained above, social belief criteria are recognized by OIE as crucial to understand a system. Social beliefs are specified in rows/columns 2 through 5 in Figure 1 and the specified belief criteria delivered by the social beliefs to institutions are found in the cells where rows 2 through 5 intersect with the institutional columns 6 through 13. The deliveries designated in the relevant cells from rows 6 through 21 to columns 6 through 21 in Figure 1 demonstrate the deliveries among the institutions that stitch together the institutional components of the system. Rows and columns 23 through 30 represent the system's environment outside the system that, as explained above, Valentinov has emphasized as important when making instrumental-ceremonial judgments about a system. As demonstrated with the cells in Figure 1, systems that are open to their environment are influenced by that environment and, therefore, must be considered in modeling any system.

\section{Cell $(1,2)$ To Uphold the Covenant Delivery to Bayit Leumi}

The cultural value criterion, To Uphold the Covenant, is an overarching criterion delivered to the social belief Bayit Leumi in cell $(1,2)$ of Figure 1. "Values are cultural criteria or evaluative standards for judgment with regard to what is ideal. They are the ultimate criteria in the sense that they are above social institutions. They are the focal criteria that are the locus to which all social criteria attempt to conform" (Hayden 2006, 76). Jewish social beliefs (rows/columns 2 through 5 in Figure1) that relate to the WZO are grounded in and derived from the idea of a covenant. The definition of covenant states that humans establish institutions and relationships on the grounds of a fundamental equality where participation is free and optional. This means that within a covenantal society, human freedoms and rights are highly emphasized and valued. Covenantal relationships contrast with those of a hierarchical nature in which everyone has his or her place and varying levels of power (Elazar 1996). Common examples of covenants are biblical. Daniel Elazar explains that biblical covenants exemplify that God does not rule hierarchically; rather, God empowers humans to rule themselves (1996). That Jews are covenantal is both a religious and secular characteristic that transcends the various ethnic groups to which Jews belong. The equality of free people is the foundation of a covenantal partnership of relationship. They tend to act on agreements derived from negotiation and bargaining (Elazar 1996, 1). The cultural value "To Uphold the Covenant" 
indicates that a Jewish people will approach relationships, institutions, and organizations with the intention to negotiate as equals. "To Uphold the Covenant" delivers to Bayit Leumi, the core social belief with respect to the Zionist enterprise. Bayit Leumi refers to the rebuilding of the Jewish national homeland in Israel and national unity. This social belief is affected by the aforementioned cultural value, as it is a belief that an equal people commonly subjected to discrimination should be brought together on a physical common ground. Bayit Leumi, in offering refuge, recognizes the equality of man, and its focus on unity is a direct result of covenantal thought.

\section{Cell $(1,3)$ To Uphold the Covenant Delivers to Medina Yehudit}

See the explanation above of Cell $(1,2)$ about the Uphold the Covenant value criterion. Medina Yehudit, or Medinat Hayehudim identifies Israel as both a Jewish state and a state of the Jews. This means that, while Israel embodies the belief expressed by Bayit Leumi that Jews should have a home, it also should have Jewish characteristics (Elazar 1996, 1). These characteristics include national Jewish iconography as well as recognition of the Jewish calendar reflected in the workweek and in schools and government. This belief maintains that religious law should take priority over democratic principles. There is a statistical divide in this social belief among Israeli Jews, however, in the event that religious law and democratic principles should actually come into conflict. As can be seen in Table 1 for cell $(1,3)$, Haredi Jews (the more Orthodox faction), tend to prioritize religion above democratic principles, while Hiloni Jews (the secular population) rarely prioritize religion above democratic principles. 
Table 1. Percentages Regarding Religious Law vs. Democratic Principles, Relevant to Cell $(1,3)$

Percent of Israeli Jews Who Believe

That Religious Law Should Take

Priority Over Democratic Principles

$\begin{array}{lc}\text { All Jews } & 24 \% \\ \text { Haredi } & 89 \% \\ \text { Dati } & 65 \% \\ \text { Masorti } & 23 \% \\ \text { Hiloni } & 1 \%\end{array}$

Variations of moderately religious and secular Jews, including Dati and Masorti, lie in the middle statistically, as shown in Table 2 (Mitchell 2016). Medina Yehudit also requires that a majority Jewish population must exist in the country.

Table 2. Percentages Regarding Necessity of Jewish State, Relevant to Cell $(1,3)$

Percent of Israeli Jews Who Believe

a Jewish State Is Necessary for

Long-Term Survival of the Jewish People

$\begin{array}{ll}\text { All Jews } & 91 \% \\ \text { Haredi } & 65 \% \\ \text { Dati } & 95 \% \\ \text { Masorti } & 97 \% \\ \text { Hiloni } & 93 \%\end{array}$

Although this belief is difficult to achieve and morally justify in the international community, its advocates see it as a duty to the Jewish people in memory of the Holocaust. Table 2 lists the percentage of Israeli Jews who say a Jewish state is necessary for the long-term survival of the Jewish people. While there is contention between Haredi and Hiloni Jews as to whether a state should be Jewish or democratic in its governance, there is little disagreement about whether a Jewish State is necessary for the survival of the Jewish people (Mitchell 2016). Medina Yehudit is a representation of Zionism that addresses the failure of emancipation and recognizes the existential threat of antisemitism to the Jewish culture (Aberbach 2009, 271). 
The belief of Medina Yehudit is a response to the problem of Jewish homelessness and maintains that the state should mirror the religious preferences of its inhabitants. The intention of the Jewish state, to fill a gap in human equality, widened throughout the history of antisemitism and fronted by the Holocaust, indicates that Medina Yehudit is of covenantal principles.

\section{Cell $(1,4)$ To Uphold the Covenant Delivers to Eretz Israel}

See Cell $(1,2)$ above for an explanation of the Uphold the Covenant value criterion. Eretz Israel is the belief that the land of the Jewish people is specifically the land of Israel, and is concerned with the use of the land, its ownership, and its sanctity (Elazar 1996, 1). This belief indicates that the Jewish homeland is Israel, as defined by the 1967 borders, and is often considered covenantal in reference to the land being promised by God to the Jewish people. The land should garner respect ecologically, and it is the responsibility of its inhabitants to refurbish it. Eretz Israel is a direct result of the cultural value "To Uphold the Covenant" not only because of the implied covenant that God promised the land to the Jews, but also because the land is treated in a covenantal manner; its life valued equal to human life.

\section{Cell $(1,5)$ To Uphold the Covenant Delivers to Techiya Yehudit}

See Cell $(1,2)$ for explanation of the value criterion To Uphold the Covenant. Techiya Yehudit is the role of Israel in the revival of Jewish life, civilization, and people from a Zionist perspective, both secular and religious, and is the most divisive social belief. This belief attributes the success of the Jewish people to the state of Israel. The perception of this belief is either secular or religious. While both perspectives are different contextually in the aftermath of the Holocaust, the secular camp tends to view Zionism as a step towards normalcy and safety for the Jewish heritage, while religious Jews tend to see Zionism as a way to restore the Jewish spirit and denomination (Elazar 1996, 1). In either sense, "To Uphold the Covenant" delivers to the beliefs of national revival in Techia Yehudit through its message to nourish Jewish heritage and religion in an effort to equalize the prosperity of the country and people in the international community. 


\section{Cell $(2,6)$ Bayit Leumi Delivers to WZO Congress}

To offer refuge, recognize equality, and provide unity to Jewish people are the criteria Bayit Leumi delivers to the WZO Congress. The Zionist Congress is the supreme legislative authority within the governing body of WZO. Article 13 of the WZO Constitution determines that, "An Ordinary Congress shall meet at least once in four years at a place and time determined by the council. It shall be convened by the Executive ..." (Resolutions of the Zionist Congress 2015), although a vote often defers, and it meets every five years. Congress occurs in five stages. It opens with a speech by the chairman of the Executive, election of Congress presidium, followed by a report of the President of the Supreme Court, and the election of congressional committees. Next, a new Executive team is elected, proposed by Congressional standing committee. The committees meet, members submit reports and vote, as well as see proposals for members of the General Council, Comptroller Office, and legal institutions. The session concludes with a closing ceremony. The Congress is responsible for electing the Chairman, Vice Chairman, and members of the Zionist Executive, as well as members and deputies of the Zionist General Council, the president of the Zionist Supreme Court, the attorney of the WZO, and the Comptroller Office. Delegates to Congress do not exceed 500, excepting delegates representing international bodies or elected from the World Election Lists (About the Zionist Congress 2015). The composition of the standing Congress is listed in Table 3, where the various political parties elected are listed, as well as the composition of previous years. Of the 500 congressional delegates, 38 percent are Israeli, 29 percent are American, and 33 percent are from Diaspora countries (The Knesset 2018). 
Table 3. Composition of Zionist Congress Relevant to Cell $(2,6)$

$\begin{array}{lrrr}\text { Party } & \text { 37th Congress } & \text { 36th Congress } & \text { 35th Congress } \\ \text { Arzenu } & 78 & 83 & 82 \\ \text { Confederation } & 22 & 18 & 16 \\ \text { Gil } & 0 & 0 & 14 \\ \text { Herut } & 0 & 5 & 5 \\ \text { Kadima/Hanoar Hatzioni } & 16 & 69 & 76 \\ \text { Kulanu } & 19 & 0 & 0 \\ \text { Likud } & 85 & 76 & 45 \\ \text { MERCAZ } & 42 & 59 & 55 \\ \text { Meretz } & 29 & 33 & 32 \\ \text { Mizrachi } & 82 & 86 & 96 \\ \text { Over the Rainbow } & 5 & 0 & 0 \\ \text { Shas } & 17 & 20 & 0 \\ \text { Yesh Atid } & 21 & 32 & 0 \\ \text { Yisrael Beytenu } & 28 & 43 & 27 \\ \text { Zionist Union } & 61 & 1 & 57 \\ \text { Undefined } & 4 & 525 & 8 \\ \text { Total Elected Delegates } & 509 & & 513\end{array}$

The composition of the 38 percent of Israeli delegates is proportionate to their party's representation in the Knesset, which is the Israeli legislative body (Results of Elections to the Zionist Congress 2015). The percent of each Israeli political party represented in the Knesset is in Table 4. Bayit Leumi, the belief that a Jewish national home should be built in Israel, delivers to the Congress in the required characteristics of its delegates. It is required that the delegates and their associated political parties be outwardly Zionist, though this is not required of all WZO affiliate organizations. This means that they are in favor of the belief of Bayit Leumi and all it entails. Bayit Leumi directly affects the following concerns in the most recent congressional agenda: "Non-Stop Zionism," "The Unity of the Jewish People," "Deepening the connection between Israeli Society and Communities of Israeli Yordim in the Diaspora," "Zionist Movement Activity in Light of Escalating Antisemitism," "Prevention of Assimilation," "Aliyah," "Absorption of Ethiopian Jews," "Refining Israel's Existence as a Jewish and Democratic State," "Democracy in Israel," "Separation of Religion and State," and "The National Institutions in the Mirror of Time." 
Table 4. Composition of Knesset, Relevant to Cells $(2,6)$ and $(14,6)$.

$\begin{array}{lrr}\text { Party } & \text { Seats } & \text { Percent of Total } \\ \text { Likud } & 30 & 18.18 \\ \text { Zionist Camp } & 24 & 14.54 \\ \text { Joint List } & 13 & 7.87 \\ \text { Yesh Atid } & 11 & 6.66 \\ \text { Kulanu } & 10 & 6.06 \\ \text { Habayit Hayehudi } & 8 & 4.84 \\ \text { Shas } & 7 & 4.24 \\ \text { United Torah Judaism } & 6 & 3.63 \\ \text { Meretz } & 5 & 3.04 \\ \text { Yisrael Beitenu } & 5 & 3.04 \\ \text { Signle MK } & 1 & 0.60\end{array}$

Belief concerns directed by Bayit Leumi are numerous because the rebuilding of a Jewish nationalism is a broad task that requires ideological work as well as physical action (Elazar 1996, 1). They all relate specifically to the idea of a national home in Israel, whether this is through encouraging immigration and Israeli nationalism, discouraging assimilation in other countries, or better defining religious characteristics of government. While this social belief has an overarching applicability to many of the affairs of Congress, it articulates very specific standards as to how the affairs should occur.

\section{Cell $(2,7)$ Bayit Leumi Delivers to the Central Elections Committee}

To ensure that all Jews can vote in every electoral area is the criterion Bayit Leumi delivers to the Central Elections Committee. The Central Elections Committee, within the Congress, is responsible for making sure membership campaigns and elections occur in every electoral area (Resolutions of the Zionist Congress 2015). They may take action in any area where there is suspicion that elections might not take place. The committee chair is a judge from Israel and can be observed by previous participants in Congress (About Zionist Congress 2015). Bayit 
Leumi delivers the belief that supports a national Jewish home in Israel, which is observable in this institution in its efforts to ensure that all Jews can vote on the delegates who attempt to organize the movement (Elazar 1996, 1).

\section{Cell $(2,8)$ Bayit Leumi Delivers to the Area Elections Committee}

To ensure that all Jews can vote on every electoral area is the criterion Bayit Leumi delivers to the Area Elections Committee. Bayit Leumi delivers to the Area Elections Committee in a similar way that it does to the Central Elections Committee, in that it emphasizes the importance of Jewish participation in the selection of delegates to lead the Jewish people to a national home (About Zionist Congress 2015). The Area Elections Committee differs from the Central Elections Committee in that the former is responsible for the conduct of an election at a specific location, whereas its superior is only responsible for ensuring that elections occur. It exists to properly implement the provisions related to congressional elections (Resolutions of the Zionist Congress 2015).

\section{Cell $(2,9)$ Bayit Leumi Delivers to World Unions}

To require branches in at least five countries and that all members be Zionists are the criteria Bayit Leumi delivers to the World Unions. World Unions refer to Zionist organizations, which represent a special ideological point of view within the WZO. A World Union must have branches in at least five countries with substantial Jewish populations and be represented by a Congress Grouping (About the Zionist Congress 2015). Every member of a World Union must be a declared Zionist, which contrasts with International Jewish Organizations that participate in WZO congressional activities. There are twelve organizations that qualify as unions, but the most prominent are the political coalitions of the World Zionist Union, composed of the Labor Zionist Movement, Arzenu, and the World Union of Meretz; the World United Faction, including Kadima-HaNoar, and Hatzioni-MERCAZ; the World Mizrachi/Ichud le'umi/Herut/Yisrael Beytenu; the World Likud/Shas; and the Hadassah/ Confederation. The qualification for Union participation itself, that each member be a declared Zionist, is evidence of a delivery from Bayit Leumi, that Jews should have a home in Israel (About the Zionist Congress 2015). Because this 
characteristic touches each World Union, their participation in the activities of Congress is further evidence of a delivery of criteria from Bayit Leumi to Congress, as explained above in cell $(2,6)$.

\section{Cell $(2,10)$ Bayit Leumi Delivers to the General Council}

To sustain the WZO in legislative decisions between congressional sessions is the criterion Bayit Leumi delivers to the General Council. The Zionist General Council (further explained in future cells) is the supreme institution of the Zionist movement during inter-congressional periods. It has all the same powers as Congress, minus those specifically reserved. The General Council is responsible for day-to-day legislative activities being completed (About the Zionist Congress 2015). They inspect and implement decisions made by other bodies within the WZO, which will be further defined in future cells. The criteria delivered by Bayit Leumi is present in the legislative decisions made by General Council. Beyond this, the General Council embodies the beliefs of Bayit Leumi in its efforts to sustain the WZO as a whole between congressional sessions.

\section{Cell $(2,11)$ Bayit Leumi Delivers to the Executive}

To perform managerial functions of the WZO is the criterion Bayit Leumi delivers to the Executive. The Executive is composed of a Chairperson, a Vice Chairperson, and a number of members intended to manage the day-to-day affairs of the WZO in Israel and the Diaspora. As the managerial institution of the WZO, the Executive must carry out the decisions made by Congress and the General Council. It operates through a series of departments, including those of Religious Affairs, Settlement, Education, Aliyah Promotion, Israel and Combatting Antisemitism, and Diaspora Activities. The common goal among these departments is to strengthen the Zionist identity and the centrality of the State of Israel in the life of Jewish people (About the Zionist Congress 2015). The promotion of these departments is a clear embodiment of criteria delivered from Bayit Leumi to the Executive because each department employs a different method to uphold the belief that a Jewish national home should exist in Israel. This goal is non-controversial in the Jewish community at large. For example, at least 98 percent of all Israeli Jewish groups believe that Jews around the 
world should have the right to make Aliyah, or migration to the land of Israel (Mitchell 2016).

\section{Cells $(3,7)$ and $(3,8)$ Medina Yehudit Delivers to Central Elections Committee and Area Elections Committee}

To allow only Jews to vote is the criterion Medina Yehudit delivers to the Central Elections Committee and Area Elections Committee. Medina Yehudit, the belief that Israel should exist as a Jewish state and a state of Jews relates specifically to elections and, therefore, the Central and Area Elections Committees. Thus, political discussions in Israel remain within the context of the state's Jewish character, and how, if non-Jewish residents were allowed to vote, that character could be lost very quickly. However, Israel and the WZO alike are also democratic states modeled after European governments. To maintain the Jewish characteristic of the Zionist enterprise, only Jews can vote in WZO elections (About the Zionist Congress 2015). This is one way that Medina Yehudit delivers to elections committees. While criteria offered by Medina Yehudit create the standard that only Jews can vote in Zionist elections, they also deliver the will for the organization to reach out to Jews to vote in the election. For example, it is the responsibility of the Central Elections Committee, as mentioned above in cell $(1,7)$, to personally see to elections that may not otherwise occur. This, as well as other functions of the Central and Area Elections Committees, are priority because of Zionist criteria offered by Medina Yehudit.

\section{Cell $(3,13)$ Medina Yehudit Delivers to the Comptroller Office}

To conduct independent accountability reviews is the criterion Medina Yehudit delivers to the Comptroller Office. The Comptroller Office is responsible for conducting an independent review of the WZO departments, the national funds, and its other bodies, as defined in the WZO Constitution. The Comptroller's responsibility is to determine that operations are within the budgetary and legal norms while demonstrating budgetary discipline, financial accountability, efficient administration, and moral integrity. The Comptroller also hears public complaints concerning the bodies that are under its review (About the Zionist Congress 2015). Medina Yehudit, the idea that Israel is a Jewish state with 
corresponding characteristics, makes deliveries to the Comptroller Office through its idealistic undertones. Because Medina Yehudit is covenantal, the respect and mutuality associated with the cultural value "To Uphold the Covenant" is embedded in this social belief (Elazar 1996, 1). Therefore, an institution responsible for the integrity of an international organization represents this social belief. That is to say, because the ideal Jewish character is one that upholds a covenant, or a promise approached with respect and equality, an institution formed on the basis of this criterion is one that values integrity, morality, and accountability. In this way, Medina Yehudit delivers to the Comptroller Office.

\section{Cell $(4,6)$ Eretz Israel Delivers to Congress}

To protect the ecology of the land and its ownership rights are the criteria Eretz Israel delivers to Congress. (Eretz Israel is defined above in the explanation of cell $(1,4)$ ). Because Eretz Israel deals with issues about the use and ownership of the land of Israel, its deliveries to the Zionist Congress are numerous. Congressional resolutions most directly affected by the criteria delivered by Eretz Israel include: "Recognition of the Jewish People as Indigenous to the Land of Israel," "Preserving a Healthy Climate for Israel's Future," and "Protecting Israel's Water Supply from Pollution" (Resolutions of the Zionist Congress 2015). Each of these criteria relate to the protection of the ecology of the land and/or its ownership, which are concepts relating to the aforementioned social beliefs.

\section{Cell $(4,9)$ Eretz Israel Delivers to World Unions}

To take action to protect the ecology of the land and its ownership rights are the criteria Eretz Israel delivers to World Unions. The unions most involved in the perpetuation of Eretz Israel include Mercaz Olami, the World Confederation, World Likud, World Meretz, World Yisrael Beytenu, and World Mizrachi (Israel's Zionist Political Parties n.d.). Of these, World Meretz is the only one that specifically prioritizes ecological issues, including environmental degradation and animal welfare (Israel's Zionist Political Parties n.d.). The other unions address the concept 
of Israeli ownership through campaigns that promote the State of Israel in the various countries in which the Union has branches.

\section{Cells $(4,10)$ and $(4,11)$ Eretz Israel Delivers to the General Council and the Executive}

To take action in an urgent, diligent, and relentless manner is the criterion Eretz Israel delivers to the General Council and the Executive. The General Council is responsible for the undertakings of Congress between sessions. The Zionist General Council must work every day, as is expressed in the congressional resolution "NonStop Zionism," to maintain Eretz Israel in the face of the international community (Elazar 1996, 1). As the human rights violations in Palestinian populations become increasingly public, the fundamental issue of ownership of the land is at stake. It is, therefore, important that Eretz Israel deliver to the General Council the criterion of urgency if the WZO is to continue its Zionist agenda. This social belief affects the Executive body of the organization in a similar way. However, its effects on the Executive more easily produce results, since the Executive oversees all departments. For example, the emphasis on ownership of the land is an evident belief in the Settlement Division activities, which seek to subsidize settlement housing for Israelis moving to the growing areas. While this division encourages specific moves within Israel, the Aliyah Department encourages Jews to move into Israel. Both of these departments operate under the preconceived notion that the land is under their ownership as a Jewish people. These departments under the Executive branch of the WZO are evidence of Eretz Israel deliveries to the General Council and the Executive.

\section{Cells $(5,7)$ and $(5,8)$ Techiya Yehudit Delivers to the Central Elections Committee and the Area Elections Committee}

To revive the Jewish livelihood and civilization in Israel is the criterion of Techiyo Yehudit, which delivers to the Central Elections Committee and the Area Elections Committee. Techiya Yehudit is the most divisive social belief in Israel, and therefore delivers the most impactful criteria to elections committees. Its fundamental notion is that the Jewish livelihood and civilization should exist in Israel. Information about its divisions can be found in cell $(1,5)$ above, where "To Uphold the Covenant" delivers 
to Techiya Yehudit. This belief delivers to the elections committees as they engage Diaspora communities in elections that connect them with Israel and Jewish culture. This effect continues in Israeli communities where engagement levels are already high. The divisive nature of Techiya Yehudit exists in the elections committees because they allow the religious and secular Jews to vote for representatives that best reflect their view of Zionism. More information about the two perspectives on Techiya Yehudit can be found above in cell $(1,5)$.

\section{Cell $(6,6)$ Congress Delivers to Congress}

There is a feedback loop within Zionist Congress where its members evaluate their own resolutions. First, the Congress elects committees that hear resolutions and proposals. Then, the larger Congress discusses and votes on the committee decisions (About the Zionist Congress 2015).

\section{Cells $(6,10),(6,11),(6,12)$ and $(6,13)$ Congress Delivers to the General Council, Executive, Supreme Court, and Comptroller Office}

Congress is responsible for electing members of the Zionist General Council to serve until the next congressional meeting occurs, where new members are elected. This process is repeated for Chairman, Vice Chairman, and members of the Executive; deputies of the General Council; President of the Supreme Court; attorney of the WZO; and the Comptroller Office. Beyond selecting the leaders of the organization, Congress is responsible for drawing up the official policy of the WZO to be implemented by all of the subordinate institutions (About the Zionist Congress 2015). Further responsibilities of Congress are in cell $(2,6)$.

\section{Cells $(6,27),(6,28)$ and $(6,30)$ Congress Delivers to Palestine, Iran, and the United Nations}

The Zionist Congress addresses international issues including the Palestinian threat and Iranian aggression. They are both considered threatening to efforts at Aliyah and Israeli nationalism. Therefore, Congress resolves that the WZO and its entities within the Israeli government and Jewish communities work to eradicate anti- 
Semitism. Calling upon the United Nations to act in an unbiased manner is a method of achieving this goal (About the Zionist Congress 2015). These "calls to action" are the deliveries made to the UN, while the actions that come with these calls are the deliveries made to the Palestinian population and Iran. The WZO has soft power, which it uses in an effort to stabilize the region so it can achieve its Zionist goals. However, the percentage of people who say peace in the region is possible is a fluctuating statistic. In 2015, Israelis and Arabs felt equally confident about peace, as they did in 2013, while 2014 showed a 14 percent increase in confidence for Arabs and a 7 percent decrease for Israelis (Mitchell 2016). While these indicators relate specifically to the belief in the possibility of peace, this information is indicative of the deliveries that Congress makes to Palestine, Iran, and the United Nations. Belief in peace between these two parties shows the momentum of actions that Congress undertakes and its ability to deliver effectively its will to the system environment.

\section{Cells $(7,6)$ Central Elections Committee Delivers to Congress}

The Central Elections Committee is responsible for synthesizing the results of the various area elections and announcing the chosen delegates three months prior to the congressional meeting (About the Zionist Congress 2015).

\section{Cells $(7,8)$ and $(8,7)$ Central Elections Committee Delivers to Area Elections Committee and Area Elections Committee Delivers to Central Elections Committee}

This relationship is one of a governing body delivering messages to its various subordinates and each individual subordinate delivering information back up the chain. The Central Elections Committee delivers information to the Area Elections Committee about when and where to hold elections, while the Area Elections Committee decides the best way to carry out the process based on the specific needs of the location. Once it has received the voter information, it is delivered back to the Central Elections Committee. More on each individual institution can be found in the explanation above for cells $(2,7)$ and $(2,8)$. 


\section{Cells $(8,26),(8,27)$ and $(8,29)$ Area Elections Committee Delivers to the Diaspora, Israel, and the United States}

Because the countries of the Diaspora are numerous, the Area Elections Committee (AEC) determines the distribution of elections. They occur in Israel, the United States, and determined Diaspora communities, at the frequency deemed necessary. The AEC delivery to these locations is the election process. These duties are further clarified above in cell $(2,8)$.

\section{Cell $(9,6)$ World Unions Deliver to Congress}

The definition of World Unions can be found above in cell $(2,9)$. It is common for World Unions to send proposals and observations for deliberation by Congress and, if accepted, included in the final congressional resolution (About the Zionist Congress 2015).

\section{Cell $(9,14)$ World Unions Deliver to the Likud Party}

The World Likud global World Union has extensive momentum in the WZO because of the Likud Party's popularity in Israel. The Likud Party itself, an institution represented in Israeli society that responds both to the Israeli government and to the $\mathrm{WZO}$, is the right-wing majority political party in Israel headed by Benjamin Netanyahu. Likud, meaning "consolidation" in Hebrew, maintains that peace and security are its central objectives. It believes in both the urban and rural settlement of Israel, and campaigns on security and national identity (Likud Party: Original Party Platform 1977). The World Likud global World Union delivers international exposure to the Likud Party, as well as unity among members outside of Israel's borders. World Unions bring the Likud party agenda to local Zionists as it advocates for the education and the national spirit of Israel both domestically and internationally. 


\section{Cell $(9,20)$ World Unions Deliver to Yisrael Beytenu}

The World Yisrael Beytenu Movement is the international Zionist organization that represents the Israeli political party Yisrael Beytenu. The organization's global efforts intend to connect Russian-speaking Jewish communities to the Zionist movement (Our Agenda 2015). Their enhanced representation is to strengthen their influence in decisions that affect the Jewish people and the State of Israel. The global reach of the World Unions delivers greater coverage to Yisrael Beytenu with respect to the constituents they attempt to motivate.

\section{Cell $(9,21)$ World Unions Deliver to Meretz}

The World Union of Meretz is the WZO affiliate with the Meretz political party in Israel. It considers itself the progressive representative of Zionism and Judaism in the Diaspora. It supports human rights within the State of Israel and the occupied Palestinian territories, as well as civil rights for all citizens, including Israeli-Arabs, women, and the LGBTQ community. They work on animal and environmental welfare issues in their host countries, and are strong supporters of the two-state solution and the Israeli-Palestinian peace process (Israel Political Parties: Meretz n.d.). Again, the World Union globalizes the outreach of political parties that its Israeli chapters would not otherwise achieve.

\section{Cell $(9,22)$ World Unions Deliver to Voter Behavior}

World Unions disseminate political agendas to Zionist individuals across the globe (Resolutions of the Zionist Congress 2015). World Unions' presence alone is an effort to garner support for the various political parties they represent. Individuals exposed to the messaging of Zionist World Unions has an impact on voting behaviors in countries where Zionists are otherwise isolated. David Weaver (1991) indicates that voters expose themselves to messaging based on their degree of interest in the message, uncertainty about the subject, and effort required to receive the message. In spreading to countries globally, World Unions minimize the effort needed for Zionists to expose themselves to political agendas. Based on the understanding that 
political agendas have a direct influence on voting behavior, World Unions deliver messaging that affects voter behavior.

\section{Cell $(10,6)$ General Council Delivers to Congress}

Congress is responsible for receiving and considering reports delivered by the General Council. They also deliberate on reports delivered to the General Council (About the Zionist Congress 2015). More information on the functions of Congress can be found in cell $(2,6)$, and more information on the General Council can be found in cell $(2,10)$.

\section{Cell $(10,11)$ General Council Delivers to the Executive}

Primarily, the General Council sends decisions to the Executive and for management through the various departments it oversees. More on these departments can be found in cell $(2,11)$. Beyond that, the General Council must elect new members of the Executive team should a seat become vacant in an inter-congressional period. The election should occur at the next session of the General Council or during the intersession period via mail or fax, though 50 percent of the Council must vote for the election to be considered valid (About the Zionist Congress 2015).

\section{Cell $(11,6)$ Executive Delivers to the Congress}

Congress receives and considers the reports of the Executive team, which are generally reviews of the various departments under their jurisdiction, elaborated on in cell $(2,11)$. For more on congressional duties, see cell $(2,6)$.

\section{Cell $(11,10)$ Executive Delivers to the General Council}

The Zionist General Council receives and considers the reports of the Executive, which, as previously indicated, is generally a synopsis of the activities in their subordinate departments. The General Council is the authority that ensures that the Executive is running smoothly. Therefore, deliveries include reports of all Executive activities to the General Council. 


\section{Cells $(11,25)$ and $(11,26)$ Executive Delivers to the Diaspora and to Israel}

The Executive delivers to countries of the Diaspora and the State of Israel through its various departments listed above in cell $(2,11)$. As previously indicated, the common goal between each of these departments is to strengthen the Zionist identity and the centrality of the State of Israel in the lives of Jewish people. These departments work on the ground in both Israel and globally to try to achieve this goal. In Table 5, under cell $(11,24)$, is listed the percentage of Jewry in the top ten Jewish populated Diaspora countries.

Table 5. Percentage of Jewry in Top Ten Diaspora Countries

$\begin{array}{llrr}\text { Rank } & \text { Country } & \text { Population } & \text { Percentage of Jewry } \\ 1 & \text { Israel } & 6,336,400 & 44 \% \\ 2 & \text { United States } & 5,700,000 & 39.5 \% \\ 3 & \text { France } & 460,000 & 3.2 \% \\ 4 & \text { Canada } & 338,000 & 2.7 \% \\ 5 & \text { U.K. } & 290,000 & 2.0 \% \\ 6 & \text { Argentina } & 180,000 & 1.3 \% \\ 7 & \text { Russia } & 179,500 & 1.2 \% \\ 8 & \text { Germany } & 177,000 & 0.8 \% \\ 9 & \text { Australia } & 113,000 & 0.8 \% \\ 10 & \text { Brazil } & 94,200 & 0.7 \%\end{array}$

WZO executive activities are more prevalent in the more populated countries (Vital Statistics: Jewish Population of the World 1998). For example, in 2012, the department concerned with both Israel and combating anti-Semitism undertook project Mifgashim, a joint project of the department and the Ministry for Development of the Negev and Galilee. It arranged for encounters between teenagers from the Diaspora and peers from Negev and Galilee to enable the visitors to become acquainted with Israel in general. It also provided the opportunity for Israelis to learn about Jewish communities in the Diaspora. Through this project, the Executive delivered understanding, interaction, and communication among teens to 
communities in Israel and the Diaspora (About the Zionist Congress 2015). The Executive continues to make exchanges like this today among its various departments through numerous partnerships.

\section{Cell $(13,10)$ The Comptroller Office Delivers to the General Council}

The Comptroller Office is in charge of conducting an independent review of the WZO departments, their funds, and other bodies as defined in the constitution to determine whether their operations are "legally desirable," within norms, and maintain a level of budgetary discipline and financial accountability. These findings then deliver to the audit committee of the General Council for confirmation and action (About the Zionist Congress 2015).

\section{Cell $(14,6)$ The Likud Party Delivers to Congress}

Israeli political parties, including the Likud and each party listed in the SFM rows/columns 14-21 (in Figure 1), deliver delegates to Congress proportionate to their representation in the Knesset, as is described in cell $(2,6)$ above. The composition of the Knesset can be found in Table 4, as explained under cell $(2,6)$. Table 4 includes the percent of the total positions in the Knesset held by each party, which indicates the proportion of each party's representation in the Zionist Congress. The Likud Party delivers representatives of its right-wing ideals to Congress in response to the legislation it proposes. These ideals include the prioritization of peace in the Middle East, urban and rural settlement in Israel, and heightened security to preserve the national identity (History of the Movement 2012). Smaller topics within the larger, right-wing agenda include the maintenance of Judea and Samaria under Israeli administration, the recognition of the Palestinian Leadership Organization as a terrorist organization, and the definition of Israeli borders as the land between the sea and Jordan (Likud Party: Original Platform 1977). These political stances are delivered to the Zionist Congress and affect the legislative decisions made. 


\section{Cell $(14,9)$ The Likud Party Delivers to World Unions}

The World Likud is the global organization of the Likud Party affiliated with the WZO. This relationship is described in cell $(9,14)$ above, although it must be clarified that the Likud Party is responsible for the political positions of its World Union. The Likud Party, out of Israel, therefore, delivers actionable agenda items to its various World Union branches. Agenda items focus on pro-Israel education and advocacy activities (About the Zionist Congress 2015).

\section{Cell $(15,6)$ The Zionist Union Delivers to Congress}

The Zionist Union is a joint party composed of members of the former Labor and Arzenu political factions in Israel. They both participate in Knesset under the Zionist Camp coalition. The number of seats they hold can be seen under cell $(2,6)$ in Figure 3 , as well as their representation in the Zionist Congress. The Zionist Union considers themselves reformative-progressive religious Zionists. They work to stimulate diplomatic settlement, to promote the security and permanence of Israeli borders, and encourage the renewal of bilateral negotiations with the Palestinians (Israel Political Parties: Zionist Union n.d.). The Zionist Union delivers delegates to congressional meetings, where their ideals can be seen reflected in legislation. This relationship is elaborated upon in cell $(14,6)$.

\section{Cell $(16,6)$ Yesh Atid Delivers to Congress}

As in the previous two cells, the proportion of Yesh Atid representation in both the Zionist Congress and the Knesset can be found in Tables 3 and 4, and explained under cell $(2,6)$. This center-left party appeals to the secular middle class. Since its 2012 inception, Yesh Atid has been most concerned with government reform and ending military draft exemptions for the ultraorthodox in Israel (Yesh Atid Party: History \& Overview n.d.). To understand how political parties deliver to congress, see cell $(14,6)$ above. 


\section{Cell $(17,6)$ Kulanu Delivers to Congress}

This party considers itself to be right or center-right wing and is a 2014 branch of Likud. They are similarly security-oriented and focus on economic issues related to the cost of living in Israel (Israel Political Parties: Kulanu n.d.). Kulanu delivers delegates to Congress to address topics with their interests in mind. Representation statistics of Kulanu in Zionist Congress and Knesset can be found in Tables 3 and 4 and explained in cell $(2,6)$ above.

\section{Cell $(18,6)$ HaBayit HaYehudi Delivers to Congress}

This far-right, Orthodox-Jewish party is most commonly associated with the ZionistSettler movement. They adamantly oppose the two-state solution and instead propose full Israeli citizenship to the West Bank and Gaza. They push for tax breaks for middle-class Israelis who serve in the military, and therefore deliver delegates to Congress that represent these priorities (Israel Political Parties: The Jewish Home n.d.). For statistics on HaBayit HaYehudi representation in Zionist Congress and Knesset, look under the explanation above for cell $(2,6)$ in Tables 3 and 4.

\section{Cell $(19,6)$ Shas Delivers to Congress}

Statistics on Shas representation in the Zionist Congress and the Knesset can be found in Table 4 relevant to cell $(2,6)$. To understand how political parties deliver to Congress, see cell $(14,6)$. Shas is also an ultraorthodox party in Israel, but its members support peace with the Palestinians and speak out against discrimination of any kind. This comes from the historic discrimination against the SephardicOrthodox Israelis who founded the party. They are officially a socialist party, but are willing to compromise on both economic and religious issues (Israel Political Parties: Shas n.d.). 


\section{Cells $(20,6)$ and $(20,9)$ Yisrael Beytenu Delivers to Congress and World Unions}

Statistics on Yisrael Beytenu representation in the Zionist Congress and the Knesset can be found in Tables 3 and 4 under cell $(2,6)$. To understand how political parties deliver to Congress, see cell $(14,6)$. Yisrael Beytenu is a secular, nationalist political party founded by Soviet-born Israelis. Its perspective on the peace process exists in its slogan, "No loyalty, no citizenship," in which largely Arab-populated areas of Israel would be swapped for settlements in the West Bank. It delivers delegates with these opinions to Congress as an agenda to its associated World Union, World Yisrael Beytenu, which focuses on Zionist outreach to Russian-speaking Jewish communities (Our Agenda 2015).

\section{Cells $(21,6)$ and $(21,9)$ : Meretz Delivers to Congress and World Unions}

For statistics on Meretz representation in the Zionist Congress and the Knesset, look under cell $(2,6)$ in Tables 3 and 4 . To understand how political parties deliver to Congress, see cell $(14,6)$. Meretz is a left/center-left political faction split from the Labor Party (Now the Zionist Union) in Israel. They campaign on social justice, equality, and peace with the Palestinians. They were the only party to oppose the 2014 military escalation in Gaza. They are critical of Israeli settlements and support Palestinian participation in the UN. Their associated World Union is described in cell $(9,21)$ (Israel Political Parties: Meretz n.d.). Meretz delivers a political agenda to its union and delegates to Congress (About the Zionist Congress 2015).

\section{Cell $(22,8)$ Voter Behavior Delivers to Area Elections Committee}

Cells $(7,8)$ and $(8,7)$ explain the hierarchy through which Zionist elections take place. The Area Elections Committee is responsible for obtaining voter information from the above countries eventually delivers to Congress. First, the voter behavior delivers to the AEC in the form of voting information. 
Cells $(23,9),(23,14),(23,15),(23,16),(23,17),(23,18),(23,19),(23,20)$, $(23,21),(23,22):$ Mass Media Delivers to World Unions, the Likud Party, the Zionist Union, Yesh Atid, Kulanu, HaBayit HaYehudi, Shas, Yisrael Beytenu, Meretz, and Voter Behavior

The relationship between mass media and politics is a phenomenon that often receives criticism for having an impact where it should remain unbiased. It is commonly assumed that mass media is a modification of face-to-face dialogue (Meyen, Thieroff, and Strenger 2014). However, mass media in the context of politics carries greater weight, as it has the power to defame political systems and take control of their legitimacy. Mass media has imposed conditions on the success of politics, which is the delivery made to each Israeli political party in the cells in columns 9 and 1422 across from row 23 . While before mass media, politicians and political parties used social, religious, or regional commonalities as a means to differentiate, they now must rely on mass media to generate attention from sponsors, attract voters, and legitimize decisions (Meyen, Thieroff, and Strenger 2014). In this way, the emergence of mass media has generated a mode of conduct for political parties and their associated world unions within the WZO system. Mass Media delivers to Voter Behavior when used as a tool to disseminate direct, agenda-setting messaging to voters, as outlined in Weaver (1991).

\section{Cell $(24,6)$ Knesset Delivers to Congress}

As is described in cell $(2,6)$ the WZO Congress is composed of Israeli delegates based on their representation in the Knesset. The composition can be found in Table 3 under cell $(2,6)$, and more information can be found in the text explaining cell $(2,6)$.

\section{Cell $(25,6)$ Diaspora Delivers to Congress}

The composition of the Zionist Congress is described in cell $(2,6)$, though further elaboration is needed that members of Congress come from the Diaspora community as well. In this way, the Diaspora delivers delegates to Congress. The actual composition of Congress can be found in Table 3, designated for cell $(2,6)$. 
Cells $(28,14),(28,15),(28,16),(28,17)$ and $(28,18)$ : Iran Delivers to World Unions, The Likud Party, The Zionist Union, Yesh Atid, Kulanu, HaBayit HaYehudi, Shas, Yisrael Beitenu, and Meretz

The description of each political party is in their explanatory cells as being securityoriented. For these details, see cells $(22,14),(22,15),(22,16),(22,17)$, and $(22,18)$ explained above. Iran is the most direct outside threat to Israel. Because Iran's nuclear program is allowed to develop to a certain extent, there is the potential for further development into advanced weaponry in the future. Furthermore, highranking officials in the Iranian government have openly called for the annihilation of Israel, namely by Supreme Leader Ali Khameni. Even before this, a series of presidents including Hassan Rouhani and Mahmoud Ahmadinejad had proclaimed a desire for the disappearance of Israel (Beres 2015, 179-188). The verbal aggressions combined with the potential for Iranian military strength is cause for concern among Israeli citizens. Security-oriented political parties like those listed above capitalize on this fear during election seasons, promising secure borders and military might. In this way, as Iran delivers to the Zionist political factions.

\section{Cell $(29,6)$ The United States Delivers to Congress}

The United States delivers delegates to Congress in the same manner as Knesset or the Diaspora. See explanation for cell $(2,6)$, and for more information see Table 3 under cell $(2,6)$ for the exact number.

\section{Cell $(29,14)$ The United States Delivers to the Likud Party}

The Likud Party is the majority in the Knesset, and its leader, Benjamin Netanyahu, is the current Prime Minister. The United States is Israel's strongest ally and a provider of both financial aid and military support (Likud Party: Original Party Platform 1977). Because the United States is in support of the Likud in Israel, they are also in support of their delegates in Zionist Congress. 


\section{Conclusion}

So what have we learned of significance? Identifying details others can utilize when modeling with the SFM were explained while conducting the analysis. Beyond that, we want to emphasize three significant findings. First, Annie Tubadji and Peter Nijkamp, in a recent article in the Journal of Economic Issues, recognize the importance of religion in socio-economic processes by emphasizing the influence of cultural values and beliefs in the development of the political economy (2018, 176 and 181), which is consistent with the findings here. Overall, in its definition, description, and explanation, the WZO can be understood as a complex system of institutions, social beliefs, attitudes, and environmental factors. The integration of various components of the WZO, Israel, and the Diaspora countries is specified here by utilizing the SFM approach for defining a system and its surrounding environment in order to gain an understanding of the complex global system of Jewish people who are of various cultures and heritages. The purpose of the Zionist movement was to bring these people together in a state of their own. To understand why Israel is a regional geopolitical power and why it can leverage some political influence in Diaspora countries for its own economic and political welfare requires an understanding of the WZO, as outlined by the SFM and the integrated relationships among those components expressed in the SFM. By explaining the relationships expressed as deliveries among the components, it was possible to observe in the SFM presented above WZO's influence on the concerns of political economy to include equity, discrimination, land ownership rights, social provisioning, equalization of property, ideology, voting rights, globalization, power, international relations, political differences, and the socioeconomic structure. In other words, religion is important in the modern world in order to gain an understanding of the issues of interest to economists.

The second significant finding emanates from the fact that Israel is of important geopolitical interest, yet it is becoming more unstable and is losing support among Jews in the United States because of its relationship to WZO. The WZO intends to be a global organization capable of influencing local communities. However, Zionism has not always been well received. Many Jews of Diaspora communities felt patriotism for their home states after the emancipation of Jews in Europe. Jewish nationalism and European patriotism have been historically in contention with one another 
(Aberbach 2009, 269). Furthermore, a problem for the WZO is that the State of Israel was built upon European hierarchical models of government, which directly contradicts the covenantal Jewish value. Systems that are not consistent with criteria delivered by cultural values do not function properly. Elazar explains, "that the people of Israel count on a very different cultural tradition generates so many of the dysfunctional elements in Israeli society as individuals whose cultural expectations are covenantal have to work within a system whose institutional structures are hierarchical thus develop devices to bypass the formal procedures" (Elazar 1996, 1). While the WZO is founded on covenantal principles, the State of Israel is of a hierarchical nature. This inconsistency leads to many rejecting the Zionist movement as a whole, and it is a reason that is seldom recognized for Israel's being "at risk of tearing itself apart" (Halbfinger and Kershner 2018). It is also the reason that support of Israel by the Jewish community in the United States has declined. Dana Milbank reported in the Washington Post that a rabbi in the United States with prominent Zionist standing recently stated that "the current government of Israel has turned its back on Zionism" and that Israel is an "anti-Zionist government" (Milbank 2018). Milbank also quotes a sociology professor in Israel to the effect that because of the declining support of Israel by the Jewish community in the United States, that community cannot be depended upon to pressure the U.S. Democratic party to support Israel in the future as it has in the past (Milbank 2018).

The third significant finding here is with regard to an issue that has not been recognized in OIE literature with regard to instrumental analysis. As explained above, in dealing with the ceremonial-instrumental dichotomy, institutionalists recognize that it is not possible to make decisions without the identification of the legitimate belief criteria in a society. In the OIE literature we reviewed, statements about instrumental analysis contain the assumption that there is only one set of institutional belief criteria involved when conducting analysis with regard to whether an institution, system, technology, or economy is instrumental. Yet the SFM analysis above of the real-world WZO-Israeli case, the WZO and Israel have different belief criteria, and both can argue that they have legitimate standing to determine their own; thus, the Israeli system is not instrumental according to WZO criteria and the WZO system is not instrumental according to Israeli criteria. Neale argued that "a requirement for social processes ... is that they be legitimate" $(1980 \mathrm{a}, 393)$ and that "policy analysis for structuring social processes cannot be fruitful unless the social 
criteria guiding the policy analysis are fair and just" (Neale 1980b, 144-145). However, as we saw above, there is not a common set of social criteria that the WZO and Israel both agree to be legitimate. Therefore, we have discovered here the need for institutionalists to begin the task of designing the rules of instrumental analysis for cases when there is a conflict of legitimate belief criteria.

Other issues of concern for future research can use the WZO SFM as a base. First, this paper only includes Jewish social beliefs that relate to Zionist cultural value, "To Uphold the Covenant" specifically, though there are other social beliefs that can be added.

Second, we chose to include only Israeli political parties in this system, although additional political factions contribute to the Zionist Congress. This was due to the greater level of involvement of Israeli parties in the WZO compared to those outside of Israel. However, it would be an area of focus for further research to include the smaller factions and their deliveries.

Third, because Israel is a leader in the areas of science and technology an interesting study would be to add the relevant WZO components and deliveries, if any, into the SFM that assist in the transfer of scientific knowledge and technology.

\section{Notes}

1 Figures 1 and 2 are each shown split between two pages in the published article. Each can be accessed and seen as a single-page unified figure at https://digitalcommons.unl.edu/econfacpub/89/ under the title of this article.

\section{References}

1. Aberbach, David. 2009. "Zionist Patriotism in Europe, 1897-1942: Ambiguities in Jewish Nationalism." The International History Review 31 (2): 268-298.

2. About the Zionist Congress. 2015. Report of The 37th Zionist Congress. October 20, 2015. Accessed January 24, 2018. Available at http://www.wzo.org.il/congress/index.php?dir=site\&page $=$ content\&cs $=3008$ doi: 10.10800707533 2.2009 .9641156 .

3. Adkisson, Richard V. 2009. "The Economy as an Open System: An Institutionalist Framework for Economic Development." In Institutional Analysis and Praxis: The Social Fabric Matrix 
Approach, edited by Tara Natarajan, Wolfram Elsner, and Scott Fullwiler, 25-38. New York, NY: Springer Science \& Business Media.

4. Beres, Louis R. 2015. "Defending Israel against Iranian Nuclear Aggression: War, Genocide, and International Law.” Israel Journal of Foreign Affairs 9 (2): 179-188, DOI: 10.1080/23739770.2015.1049400.

5. Bush, Paul D. 1983. "An Exploration of the Structural Characteristics of Veblen-Ayres-Foster Defined Institutional Domain." Journal of Economic Issues 17, no. 1 (March): 35-666.

6. Bush, Paul D. 1987. "The Theory of Institutional Change." Journal of Economic Issues 21, 3 (September): 1075-1116.

7. Elazar, Daniel. J. 1996. "Jewish Values in the Jewish State." In Israel at 2020: A Master Plan for Israel in the 21 ${ }^{\text {st }}$ Century, edited by Adam Mazar. Haifa: The Technion. Retrieved January 24, 2018, from http://www.jcpa.org/dje/articles2/values.htm.

8. Elsner, Wolfram. 2012. "The Theory of Institutional Change Revisited: The Institutional Dichotomy, Its Dynamic, and Its Policy Implications in a More Formal Analysis." Journal of Economic Issues 46, no. 1 (March): 1-43.

9. Fullwiler, Scott T., Wolfram Elsner, and Tara Natarajan. 2009. "The Social Fabric Matrix Approach to Policy Analysis: Introduction.” In Institutional Analysis and Praxis: The Social Fabric Matrix Approach, edited by Tara Natarajan, Wolfram Elsner, and Scott Fullwiler, 122. New York, NY: Springer Science \& Business Media.

10. Gill, Roderick A. 1996. "An Integrated Social Fabric Matrix/Systems Dynamics Approach to Policy Analysis." Systems Dynamics Review 12, no. 3 (Fall): 167-182.

11. Halbfinger, David and Isabel Kershner. 2018."In Netanyahu's Israel, the Divisiveness Is Now All about Him." The New York Times, February 15, 2018: A4.

12. Hayden, F. Gregory. 2006. Policymaking for a Good Society: The Social Fabric Matrix Approach to Policy Analysis and Program Evaluation. New York: Springer.

13. Hayden, F. Gregory. 2009. "Normative Analysis of Instituted Processes." In Institutional Analysis and Praxis: The Social Fabric Matrix Approach, edited by Tara Natarajan, Wolfram Elsner, and Scott Fullwiler, 103-120. New York, NY: Springer Science \& Business Media.

14. Hayden, F. Gregory. 2018. "Military Planning in a Context of Complex Systems and Climate Change." Journal of Economic Issues 52 (2): 349-357.

15. History of the Movement. 2012. Report of The Likud Party, July 22, 2012. Retrieved January 24, 2018 from https://www.likud.org.il/en/about-the-likud/history-of-the-movement [Google Scholar]

16. Israel Political Parties: Kulanu. n.d. Report of Jewish Virtual Library: A Project of the AmericanIsraeli Cooperative Enterprise, 1998-2018. Accessed March 07, 2018. http://www.jewishvirtuallibrary.org/kulanu.

17. Israel Political Parties: Meretz. n.d. Report of Jewish Virtual Library: A Project of the AmericanIsraeli Cooperative Enterprise, 1998-2018. Accessed March 07, 2018. http://www.jewishvirtuallibrary.org/meretz-political-party 
18. Israel Political Parties: Shas. n.d. Report of Jewish Virtual Library: A Project of the AmericanIsraeli Cooperative Enterprise, 1998-2018. Accessed March 07, 2018. http://www.jewishvirtuallibrary.org/shas-political-party

19. Israel Political Parties: The Jewish Home. n.d. Report of Jewish Virtual Library: A Project of the American-Israeli Cooperative Enterprise, 1998-2018. Accessed March 07, 2018. http://www.jewishvirtuallibrary.org/the-jewish-home-political-party

20. Israel Political Parties: Zionist Union. n.d. Report of Jewish Virtual Library: A Project of the American-Israeli Cooperative Enterprise, 1998-2018. Accessed March 07, 2018. http://www.jewishvirtuallibrary.org/zionist-union-party

21. Israel's Zionist Political Parties. n.d. Report of World Zionist Organization. Accessed March 07, 2018. http://www.wzo.org.il/congress/index.php?dir=site\&page $=$ content\&cs $=3090$

22. Karaçuka, Mehmet. 2018. "Religion and Economic Development in History: Institutions and the Role of Religious Networks.” Journal of Economic Issues 52, no. 1 (March): 57-79.

23. Likud Party: Original Party Platform. 1977. Jewish Virtual Library. Accessed March 07, 2018. http://www.jewishvirtuallibrary.org/original-party-platform-of-the-likud-party

24. Mayhew, Anne. 2018. "An Introduction to Institutional Economics: Tools for Understanding Evolving Economies." The American Economist 63, no. 1 (Spring): 3-17.

25. Meyen, Michael, Markus Thieroff, and Steffi Strenger. 2014. "Mass Media Logic and the Mediatization of Politics: A Theoretical Framework.” Journalism Studies 15, no. 3 (May): 271288.

26. Milbank, Dana. 2018. "American Jews are Watching Israel in Horror." Washington Post, September 21, 2018: A5.

27. Mitchell, Travis. 2016. "Israel's Religiously Divided Society." Pew Research Center's Religion \& Public Life Project, March 08, 2016. Accessed March 07, 2018. http://www.pewforum.org/2016/03/08/israels-religiously-divided-society/. [Google Scholar]

28. Neale, Walter C. 1980a. "Market Capitalism as Dispute Resolution: The Loss of Legitimacy and the Problems of the Welfare State." Journal of Economic Issues 14, no. 2 (June): 391-398.

29. Neale, Walter C. 1980b. "Income Distribution in the Welfare State: Consequences of a Loss of Consensus in Britain." In Institutional Economics: Contributions to the Development of Holistic Economics, edited by John Q. Adams, 139-152. Boston: Martinus Nijhoff.

30. Our Agenda. Report of World Yisrael Beytenu, 2015. Accessed March 7, 2018. Available at http://worldbeytenu.org/our_agenda/.

31. Polanyi, Karl. 1994 (2001). The Great Transformation: The Political and Economic Origins of Our Time. Boston: Beacon Press.

32. Resolutions of the Zionist Congress. 2015. Report of the Zionist Congress XXXVII, Jerusalem, October 20-22, 2015. Accessed February 15, 2018 from http://www.wzo.org.il/index.php?dir=site\&page=pages\&op=item\&cs=3256\&language=eng

33. Results of Elections to the Zionist Congress. 2015. Report of the 37th Zionist Congress. October 20, 2015. Accessed March 07, 
2018. http://www.wzo.org.il/congress/index.php?dir=site\&page=content\&cs=3084 [Google Scholar]

34. Schumpeter, Joseph A. 1954 (1963).History of Economic Analysis. New York: Oxford University Press,

35. Sturgeon, James I. 2009. "The Social Fabric Matrix, the Principles of Institutional Adjustment, and Individual Action." In Institutional Analysis and Praxis: The Social Fabric Matrix Approach, edited by Tara Natarajan, Wolfram Elsner, and Scott Fullwiler, 39-54. New York, NY: Springer Science \& Business Media.

36. The Knesset. 2018. Report of the Current Knesset Members of the Twentieth Knesset 2018. www.knesset.gov.il/mk/eng/mkindex_current_eng.asp?view=1

37. Tubadji, Annie and Peter Nijkamp. 2018. "Cultural Corridors: An Analysis of Persistence in Impacts on Local Development-A Neo-Weberian Perspective on South-East Europe." Journal of Economic Issues 52, no. 1 (March): 173-204.

38. Underwood, Daniel A. and Dan Friesner. 2017. "Asset Mapping, the Social Fabric Matrix, Economic Impact Analysis and Criteria for Sustainability and Justice: Operational Elements for Holistic Policy Planning." Journal of Economic Issues 51, no. 2 (September): 813-827.

39. Valentinov, Vladislav, Stephan Hielscher, Sebastian Everding, and Ingo Pies. 2018. "The AntiGMO Advocacy: An Institutionalist and Systems-theoretic Assessment.” Kybernetics 47, no. 9 (September): 888-905.

40. Vital Statistics: Jewish Population of the World. 1998. Jewish Virtual Library. Accessed March 07, 2018. http://www.jewishvirtuallibrary.org/jewish-population-of-the-world.

41. Weaver, David. 1991. "Political Issues and Voter Need for Orientation." Agenda Setting; Readings on Media, Public Opinion, and Policymaking: 131-139.

42. Yesh Atid Party: History \& Overview. Report of Jewish Virtual Library, n.d. Accessed March 07, 2018. http://www.jewishvirtuallibrary.org/history-and-overview-of-yesh-atid-party 
Figure 1. SFM of Deliveries among WZO, Israel, and Diaspora Countries.

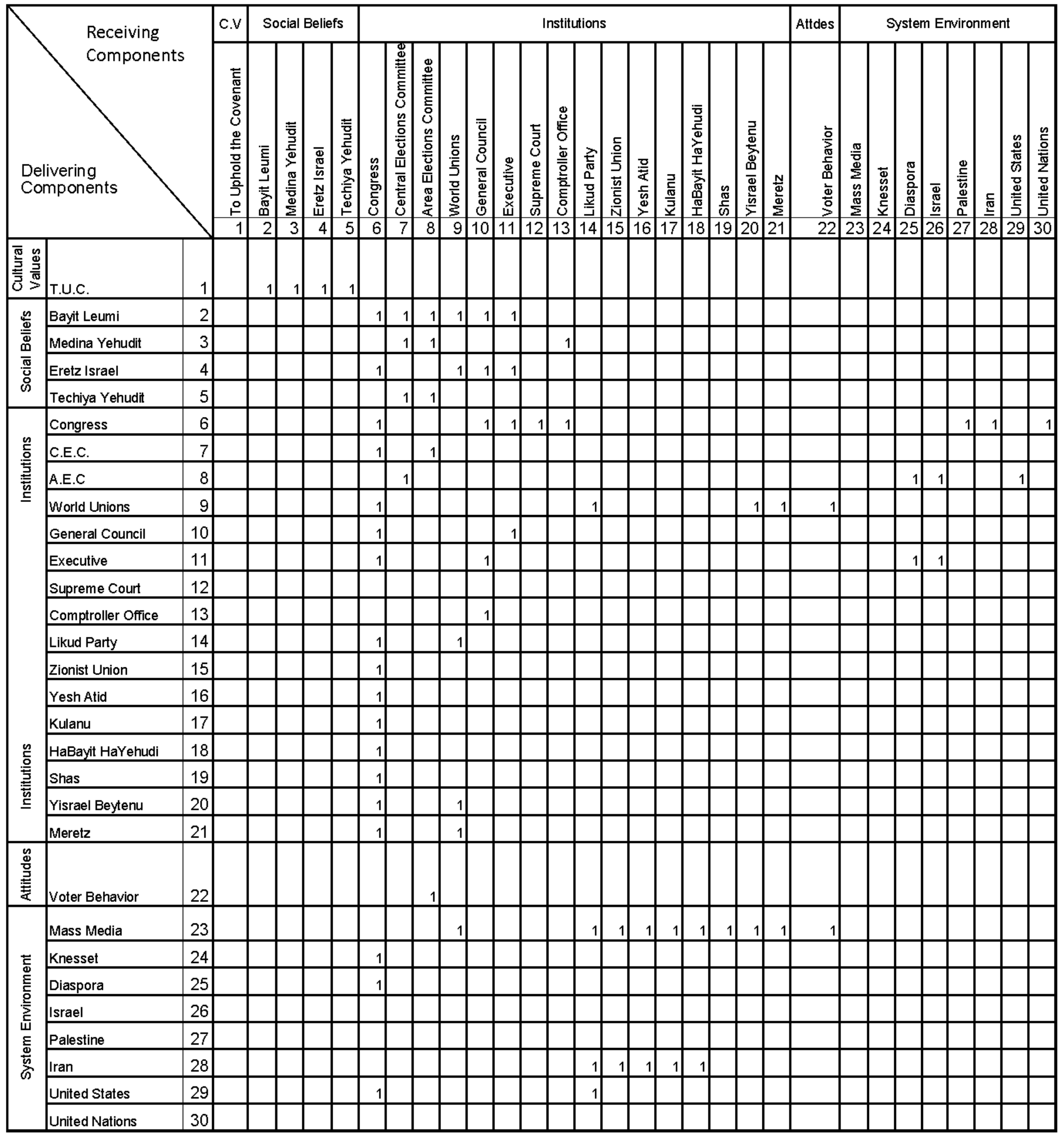


Figure 2. SFM Digraph of Deliveries among WZO, Israel, and Diaspora Countries.

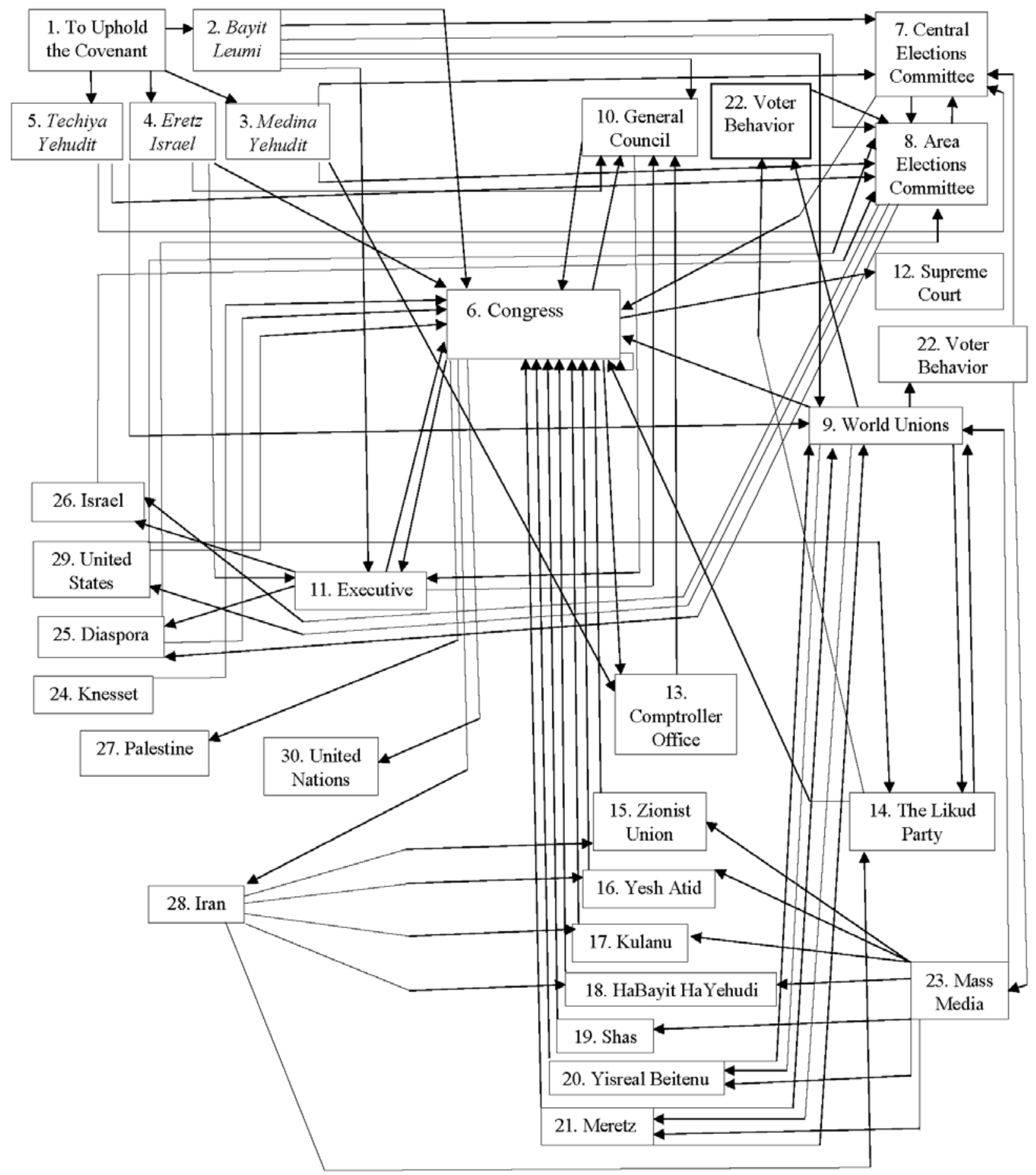

